\title{
Effect of 5-fluorouracil versus Cisplatin in Combination with Clove Oil in Management of Head and Neck Squamous Cell Carcinoma Cell Lines
}

\author{
Romissaa A. Ismail ${ }^{1 *}$, Aly F Mohamed ${ }^{2}$, Mai S. Attia ${ }^{3}$ and Eatemad A.Shoreibah ${ }^{4}$
}

Codex : 51/1910

azhardentj@azhar.edu.eg

http://adjg.journals.ekb.eg

DOI: $10.21608 /$ adjg.2019.7420.1075

\begin{abstract}
Purpose: In an attempt to reduce side effects of cancer chemotherapeutic drugs with the use of the natural product such as clove oil, as it considered that natural resources had always been a better supplement than chemicals in drug manufacture and disease treatment especially that chemicals often have hazardous short or long term side effects. The present examination was done to think about the impact of blend of clove oil with 5-fluorouracil versus clove oil with cisplatin in the treatment of head and neck squamous cell carcinoma cell lines. Material and methods: All tested sets were examined to evaluate cytotoxic effect of tested drugs by MTT assay, cell cycle analysis and level of apoptosis by flowcytometery. Result: Cell cycle analysis demonstrated that the combination of cisplatin and clove oil exhibited an increase in the percentage of apoptotic cells during the Pre-G1 phase recording 33.15\%, compared to that treated with a mix of clove oil and 5-fluorouracil recording a percentage of apoptotic cells recording $16.12 \%$ while in control cells the percentage of apoptotic cells at Pre-G1 phase recording $0.92 \%$ ( $\mathrm{P}$-value $<0.01)$. And also the combination of cisplatin and clove oil exhibited an increase in the percentage of cell growth arrest during the G2/M phase recording $30.1 \%$, compared to that treated with a combination of clove oil and 5-fluorouracil recording a percentage $22.51 \%$ while in control cells the percentage of cell growth arrest at $\mathrm{G} 2 / \mathrm{M}$ phase recording $7.11 \%$ (P-value $<0.01$ ). Conclusion: The cell cycle analysis demonstrated that the blend of cisplatin and clove oil displayed an expansion in the level of cell development capture amid the G2/M stage contrasted with other tried and it showed an expansion in the level of apoptotic cells amid the Pre-G1 stage contrasted with other tried sets.
\end{abstract}

\section{KEYWORDS}

5-FU, Cisplatin, Clove oil,

Head and neck cancer cell line

(Hep2)

(a)

- A paper extracted from Master Thesis titled "Effect of 5-fluorouracil versus Cisplatin in Combination with Clove Oil in Management of Head and Neck Squamous Cell Carcinoma Cell Lines“

1. * Demonstrator of Oral Medicine, Periodontology, Oral Diagnosis and Dental Radiology, Faculty of Dental Medicine for Girls, Al-Azhar University. Email: romiss3a@gmail.com

2. Head of serum and vaccine research Sector, Sera and Drugs (VACSERA Egy Vac)

3. Assistant professor of Oral Medicine, Periodontology, Oral Diagnosis and Dental Radiology Department, Faculty of Dental Medicine for Girls, Al-Azhar University

4. Professor of Oral Medicine, Periodontology, Oral Diagnosis and Dental Radiology Department, Faculty of Dental Medicine for Girls, Al-Azhar University 


\section{INTRODUCTION}

Malignant growth is a noteworthy overall medical issue because of the absence of far reaching and exhaustive early recognition strategies and the poor forecast of patients which analyzed in later phases of the illness. These variables advance the frequency of malignant growth on worldwide scale and genuine test is the way to control the spread of disease $^{(1)}$. Also, by 2030 the malignancy worldwide inconvenience is relied upon to develop to 21.4 million new disease cases and 13.2 million disease passing owing to the development and maturing of populace. Sadly, the future estimation of malignant growth will most likely bigger because of the execution of ways of life that are perceived to build disease chance, for example, smoking, less than stellar eating routine and physical action ${ }^{(2)}$.

Head and neck malignancies mean the seventh most far reaching disease around the world ${ }^{(3)}$. In the oral cavity, the oral squamous cell carcinoma positions as the $6^{\text {th }}$ most basic malignancy in the world $^{(4)}$. The by and large 5-year survival rate for patients trouble from oral squamous cell carcinoma is around half ${ }^{(5)}$. To information, malignancy treatment for the most part comprises of different blends of medical procedure, radiation treatment and chemotherapy yet regardless of these remedial alternatives, disease remains related with high mortality. Chemotherapeutic medications characterized as synthetic substances that can denature malignancy cells by capturing their development however sadly these medications are less particular towards disease cells ${ }^{(6)}$. Likewise, characteristic and some engineered mixes can avoid, stifle and turn around the progression of disease ${ }^{(7)}$. The mixes of characteristic root have regularly furnished as another mixes with

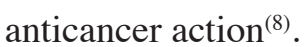

Fluorouracil (5-FU) is named a standout amongst the most every now and again endorsed chemotherapeutic medications for the administration of head and neck, bosom and gastrointestinal malignancy ${ }^{(9)}$.Despite the fact that its enemy of metabolite is poisonous, its viability makes it a standout amongst the most broadly utilized operators against strong tumors and for the most part it is endorsed in blend with different medications like cisplatin ${ }^{(10)}$. 5-FU can be fused into RNA and DNA, prompting cytotoxicity and cell passing ${ }^{(11,12)}$. Cisplatin is one of fundamental specialists in the treatment of squamous cell carcinoma of head and neck ${ }^{(13)}$. It harms tumors by inciting apoptosis, intervened by initiation of various flag transduction pathways, including calcium flagging, passing receptor flagging, and enactment of mitochondrial pathways ${ }^{(14,15)}$. Regardless of its power, the utilization of cisplatin is much of the time constrained by its toxicities, which incorporate nephrotoxicity, ototoxicity, neurotoxicity, just as extreme sickness and heaving ${ }^{(16)}$.

Clove has focusing because of the successful cancer prevention agent and antimicrobial activities emerging among alternate flavors ${ }^{(17)}$. The real part of clove oil is eugenol, to which are perceived a considerable lot of the cancer prevention agent properties $^{(18)}$. The cell reinforcement movement of eugenol may happen by various instruments, for example, scavenging the radicals and chelating metal particles. In addition, it partakes in photochemical responses, and showcases solid cancer prevention agent movement ${ }^{(18,19)}$. A mix of a few anticancer medications or utilizing drug with various components of activity considered to build disease murdering potential ${ }^{(20)}$. Cell culture innovation speaks to an accommodating device for examinations in various fields. In addition, it encourages investigation of natural properties and procedures that are not promptly effectively come to at the dimension of unblemished living being ${ }^{(21)}$. What's more, it is described by the likelihood to ascertain roughly ideal focus and span of anticancer medications for human uses ${ }^{(22)}$. 


\section{MATERIAL AND METHODS}

\section{Cell culture}

Human laryngeal carcinoma cell line (Hep2) was sympathetically provided from VACSERA culture division. Cells were kept up in RPMI 1640 medium (GIBCO - USA) enhanced with $10 \%$ fetal cow-like serum (GIBCO - USA) in a humidified air of $5 \% \mathrm{CO} 2$ at $37^{\circ} \mathrm{C}$ (Jouan - France).Confluent cells were confined utilizing $0.25 \%$ (trypsin arrangement and $0.05 \%$ ethylene diaminetetraacetic corrosive (Gibco-USA) for $5 \mathrm{~min}$.

\section{Used drugs}

5-Flourouracil (LTD-India) - cisplatin (MYLANFRANCE)-clove oil (EMA Lab-Giza).

\section{Drug preparation}

5-fluorouracil and cisplatin are sterile drugs but clove oil not sterile so, we made filtration of clove oil by 0.2 syringe filter (Millipore-USA).

\section{Design of tested sets}

Two 96 well cell culture plates (Nunc - USA) were used. The first culture plate was divided into four Sets and $(100 \mu \mathrm{L} /$ well of drug used in quadrate): Set- I: Hep2 cells treated with clove oil; Set-II: Hep2 cells treated with cisplatin; Set- III: Hep2 cells treated with 5-fluorouracil; Set- IV: non treated cells (control cells). The second cell culture plate was divided in to three Sets: Set-I: Hep2 cells treated with combination of clove oil and cisplatin (100 micro liter of clove oil +100 micro liter of cisplatin); Set- II: Hep2 cells treated with combination of clove oil and 5-fluorouracil (100 microliter of clove oil +100 microliter of 5 fluorouracil were used); Set- III: non treated cells (control cells). Tested drugs were 2 fold serially diluted on precultured cell line post decanting growth medium. After that two cell culture plates had been incubated for 24 hours at $37^{\circ} \mathrm{C}$.

\section{Cytotoxicity}

MTT (3-[4,5-dimethylthiazol-2-yl]-2,5-diphenyltetrazolium bromide) obtained from (Sigma Aldrich-USA) is a water dissolvable tetrazolium salt, which is changed over to an in solvent purple formazan by cleavage of the tetrazolium ring by succinate dehydrogenase acknowledged from the mitochondria. The formazan item is impermeable to the cell films and subsequently it gathers in sound cells. MTT $0.5 \mathrm{mg} / \mathrm{ml}$ was added to $24 \mathrm{hr}$ tried sets as $50 \mu \mathrm{l} /$ well. Plates were hatched at $37^{\circ} \mathrm{C}$ for $4 \mathrm{hr}$ in the dark.MTT recolor was tapped and recolored cells are washed twice utilizing phosphate support saline (PBS) arrangement (Biowhittaker-Belgium). Created formazan gems were broken up utilizing $0.4 \%$ fermented iso-propanol as $0.05 \mathrm{ml} /$ well. Optical thickness of broke up gems was estimated at 570 nm utilizing ELISA plate reader (Biotek-ELx-800, USA). Optical density was plotted against fixation and the IC50 of tried sets was controlled by utilizing MASTER PLEX 2010 programming ${ }^{(23,24)}$.

\section{Cell Cycle Analysis and apoptosis measurement}

Hep2 cells pre-refined in $25 \mathrm{~cm} 2$ cell culture flasks had been treated with the IC50 of tried dugs notwithstanding (E-MEM) development medium (GIBCO - USA) and after that brooded for 24hrs. After brooding morphological changes were seen by utilizing an altered stage differentiate magnifying instrument (Nikon-Japan) ${ }^{(25)}$. For cell cycle examination, the separated cells were reaped and settled delicately with $70 \%$ (v/v) Methanol and kept at $+4^{\circ} \mathrm{C}$ for 30 minutes. After that cells had been resuspended in PBS containing $40 \mu \mathrm{g} / \mathrm{mL}$ Palladium Iodide and ribonuclease (RNase) $0.1 \mathrm{mg} / \mathrm{mL}$ and $0.1 \%(\mathrm{v} / \mathrm{v})$ Triton X-100 of every a dull room. After $30 \mathrm{~min}$ at $37^{\circ} \mathrm{C}$, the cells were investigated utilizing the stream cytometery (Becton-Dickinson, San Jose, CA, USA) furnished with an argon particle laser at a wavelength of $488 \mathrm{~nm}$. 


\section{Statistical Analysis}

All analyses were completed three autonomous occasions. Results were factually dissected utilizing single direction examination of change (ANOVA) and were displayed as mean $\pm \mathrm{SD}$. The thing that matters was considered measurably critical at $\mathrm{p}<0.05$.

\section{RESULT}

\section{Cytotoxicity}

The viability percentage of tried sets was dictated by utilizing MTT assay 3-(4,5-dimethylthiazol-2-yl) 2,5 diphenyl tetrazolium bromide and determined by Master - plex-2010 program. The viability $\%$ of treated cells had been concentration dependent. The IC50 esteems were $3.54 \mu \mathrm{g} / \mathrm{ml}$, $4843.41 \mu \mathrm{g} / \mathrm{ml}, 13.00 \mu \mathrm{g} / \mathrm{ml}, 2.43 \mu \mathrm{g} / \mathrm{ml}$ and 494.98 $\mu \mathrm{g} / \mathrm{ml}$ post cell treatment with clove oil, 5-fluorouracil, cisplatin, cisplatin and clove oil and 5-fluorouracil and clove oil, separately.

Concerning cytotoxic impact of tried medications it was discovered that cells treated with blend of clove oil and cisplatin indicated increasingly harmful impact to laryngeal carcinoma cell line (Hep2) than whatever is left of tried sets those could be orchestrated in the request of a mix of clove oil and cisplatin recording $2.43 \mu \mathrm{g} / \mathrm{ml}>$ clove oil; $(3.54 \mu \mathrm{g} / \mathrm{ml})>$ cisplatin; $13.00 \mu \mathrm{g} / \mathrm{ml} 5$-fluorouracil and clove oil; $494.98 \mu \mathrm{g} / \mathrm{ml}>5$-fluorouracil; $4843.41 \mu \mathrm{g} / \mathrm{ml}$, the distinction in IC50 values was essentially elevated according to the tested medications $(\mathrm{P}<0.05)$.

\section{Cell Cycle Analysis}

\section{I) G0-G1 phase}

Statistatically, control cells showed the highly significant highest mean value followed by cells treated with clove oil, 5-FU, clove oil with 5-FU, cisplatin and clove oil with cisplatin subsequently. As shown as in (Table.1)

\section{II) S phase}

Control cells showed the highly significant highest mean value followed by cells treated with clove oil, clove oil with 5-FU, 5-FU, cisplatin and clove oil with cisplatin subsequently. (Table.1)

\section{III) Growth arrest at G2-M phase}

Cells treated with a mix of clove oil and cisplatin demonstrated the exceedingly huge most noteworthy mean esteem pursued by cells treated with clove oil and 5-FU, cisplatin, 5-FU, clove oil and control cells in this way. (Table.1)

\section{IV) Pre-G1 apoptosis}

Cells had been treated with a blend of clove oil and cisplatin demonstrated the very critical most astounding mean esteem followed by cells treated with cisplatin, 5-FU with clove oil, 5-FU, clove oil and control cells in this manner. As appeared in (Table 1).

\section{Level of apoptosis in tested sets}

\section{I) Early Apoptosis}

Tried cells treated with a blend of clove oil and cisplatin demonstrated the profoundly critical most noteworthy mean esteem pursued by cells treated with cisplatin, 5-FU with clove oil, 5-FU, clove oil and control cells hence. As shown as in (Table 2).

\section{II) Late Apoptosis}

Also, cells treated with a mix of clove oil and cisplatin demonstrated the exceedingly critical most noteworthy mean values followed by cells treated with cisplatin, 5-FU, clove oil with 5-FU, clove oil and control cells in this manner. As illustrated in (Table.2).

\section{Evaluation of necrosis in tested sets}

Tested cells treated with a blend of clove oil and cisplatin demonstrated the exceptionally noteworthy most astounding mean esteem pursued by cells treated with 5 -FU, cisplatin, clove oil and 5-FU, clove oil and control cells hence. (Table 2) 
Table (1): Cell cycle analysis

\begin{tabular}{|c|c|c|c|c|c|c|c|c|c|}
\hline \multicolumn{2}{|c|}{ Cell cycle analysis } & Control cells & Clove & 5-FU & Cisplatin & Clov + Cisplatin & Clov $+5-F U$ & Test value* & P-value \\
\hline \multirow{2}{*}{$\%$ G0-G1 } & Mean \pm SD & $67.87 \pm 2.30$ & $61.77 \pm 5.84$ & $51.30 \pm 2.66$ & $42.37 \pm 5.46$ & $24.37 \pm 4.87$ & $44.27 \pm 3.81$ & \multirow{2}{*}{37.585} & \multirow{2}{*}{0.000} \\
\hline & Range & $65.9-70.4$ & $56.8-68.2$ & $48.5-53.8$ & $36.7-47.6$ & $19.8-29.5$ & $40.3-47.9$ & & \\
\hline \multirow{2}{*}{$\% \mathrm{~S}$} & Mean \pm SD & $24.09 \pm 3.47$ & $17.67 \pm 1.42$ & $15.29 \pm 1.32$ & $14.74 \pm 1.93$ & $12.37 \pm 1.66$ & $17.11 \pm 1.48$ & \multirow{2}{*}{11.813} & \multirow{2}{*}{0.000} \\
\hline & Range & $20.4-27.28$ & $16.4-19.2$ & $13.8-16.3$ & $12.6-16.33$ & $10.8-14.1$ & $15.4-18$ & & \\
\hline \multirow{2}{*}{$\%$ G2-M } & Mean \pm SD & $7.11 \pm 1.96$ & $14.29 \pm 0.60$ & $18.49 \pm 1.18$ & $20.47 \pm 0.91$ & $30.17 \pm 2.76$ & $22.51 \pm 2.05$ & \multirow{2}{*}{59.791} & \multirow{2}{*}{0.000} \\
\hline & Range & $5.53-9.3$ & $13.6-14.7$ & $17.5-19.8$ & $19.8-21.5$ & $28.1-33.3$ & $20.5-24.6$ & & \\
\hline \multirow{2}{*}{ \%Pre-G1 } & Mean \pm SD & $0.92 \pm 0.16$ & $6.35 \pm 1.10$ & $14.89 \pm 1.97$ & $22.45 \pm 1.29$ & $33.15 \pm 1.53$ & $16.13 \pm 2.15$ & \multirow{2}{*}{171.749} & \multirow{2}{*}{0.000} \\
\hline & Range & $0.8-1.1$ & $5.3-7.5$ & $12.66-16.4$ & $21.3-23.85$ & $31.6-34.66$ & $14.68-18.6$ & & \\
\hline
\end{tabular}

$P$-value $<0.01$ highly significant $\quad P$-value $<0.05$ Significant $\quad P$-value $>0.05$ Non significant

Table (2): Level of apoptosis in tested sets

\begin{tabular}{|c|c|c|c|c|c|c|c|c|c|}
\hline \multicolumn{2}{|c|}{ Apoptosis } & Control cells & Clove & FU & Cisplatin & Clov + Cisplatin & Clov $+\mathbf{F U}$ & Test value & P-value \\
\hline \multirow{2}{*}{ Early } & Mean \pm SD & $0.47 \pm 0.07$ & $2.85 \pm 0.47$ & $4.92 \pm 0.16$ & $8.63 \pm 1.31$ & $12.27 \pm 1.15$ & $6.72 \pm 0.43$ & \multirow{2}{*}{91.758} & \multirow{2}{*}{0.000} \\
\hline & Range & $0.4-0.53$ & $2.3-3.14$ & $4.8-5.1$ & $7.6-10.1$ & $11.5-13.6$ & $6.26-7.1$ & & \\
\hline \multirow{2}{*}{ Late } & Mean \pm SD & $0.31 \pm 0.07$ & $2.72 \pm 0.76$ & $7.59 \pm 0.80$ & $11.48 \pm 0.91$ & $17.89 \pm 1.50$ & $7.19 \pm 0.69$ & \multirow{2}{*}{149.307} & \multirow{2}{*}{0.000} \\
\hline & Range & $0.25-0.39$ & $2.26-3.6$ & $6.8-8.4$ & $10.5-12.3$ & $16.3-19.27$ & $6.5-7.87$ & & \\
\hline \multirow{2}{*}{ Necrosis } & Mean \pm SD & $0.14 \pm 0.03$ & $0.79 \pm 0.17$ & $2.37 \pm 0.65$ & $2.34 \pm 0.57$ & $2.99 \pm 0.46$ & $2.21 \pm 0.37$ & \multirow{2}{*}{19.175} & \multirow{2}{*}{0.000} \\
\hline & Range & $0.12-0.17$ & $0.6-0.9$ & $1.9-3.12$ & $1.8-2.93$ & $2.5-3.4$ & $1.8-2.53$ & & \\
\hline
\end{tabular}

\section{DISCUSSION}

Cancer is a gathering of multiple hundreds neoplastic infections, which are all caused by dysregulation of various cell flagging pathways (26). Head and neck tumors spoke to the seventh most frequent disease around the world ${ }^{(3)}$. The worldwide frequency of lip, oral cavity, and pharyngeal diseases of 529,500 , relating to $3.8 \%$ of all malignant growth cases, is anticipated to increment by $62 \%$ to 856,000 cases by 2035 because of changes in socioeconomics ${ }^{(27)}$. The sorts of malignant growths are unique in relation to creating nations to created nations, where disease of the lung, bosom, colorectum and pancreas are significantly more event in created nations and disease of throat and liver are substantially more event in creating nations ${ }^{(28)}$.
Chemotherapeutic medications plan to murder malignant growth cells in the desire for forestalling further disease movement while chemoprevention incorporates administrating non-harmful operators to people who might be at an expanded danger of disease. While, chemoprevention is a promising system to diminish the event of malignancy, both in high-hazard gatherings and in the all inclusive community ${ }^{(29)}$. 5-fluorouracil (5-FU) is named a standout amongst the most usually recommended chemotherapeutic medications for the cure of head and neck malignancy ${ }^{(9)}$. It was known by impacts like bone marrow concealment and such gastrointestinal toxicities as sickness, regurgitating, loose bowels, stomatitis and both intense and deferred neurotoxicity ${ }^{(30,31)}$. 
Cisplatin is the most dynamic chemotherapeutic specialist for the treatment of various kinds of malignant growth and it is normally joined with different operators, for example, docetaxel, gemcitabine and 5-FU ${ }^{(32)}$. Be that as it may, its utilization is confined because of extreme symptoms, for example, paleness, neurotoxicity, nephrotoxicity and the achievement of medication opposition ${ }^{(31)}$.

Natural products had been the most successful resource of potential pharmaceutical agent. It represented the scaffolds in achieving chemical diversity for human use and it characterized by anticancer properties ${ }^{(33,34)}$. Eugenol (4-allyl-2methoxyphenol) is a characteristic phenolic material that is the significant part of clove oil and it is broadly utilized not just in dentistry as a constituent of zinc oxide eugenol concrete and is connected to the mouth condition, yet additionally as a fragrant and seasoning operator in various beautifying agents and nourishment item. Eugenol-related mixes not just go about as cell reinforcement and furthermore as prooxidant which might be engaged with the cytotoxicity enlistment ${ }^{(35)}$.

The lethal reactions of as of now utilized anticancer medications can be diminished by utilizing non-dangerous potentiating operator or synergistic compound in blend with anticancer medications which may potentiate their proficiency while limiting their harmfulness by decreasing the portion. Such non-lethal potentiating operators which can resolve a few issues of the clinical malignant growth treatment contain low sub-atomic weight terpenoids present in fundamental oils ${ }^{36}$, ${ }^{37)}$.Recent examinations have demonstrated that the co-treatment of an antitumor specialist with an enemy of disease regular item can be one of the potential helpful systems diminishing the degree and seriousness of malignant growth treatmentrelated poisonous quality ${ }^{(38)}$.

Cell culture speaks to a valuable device for examinations in various fields and it encourages investigation of natural properties and procedures that are not promptly reachable at the dimension of unblemished living being ${ }^{211}$. Three-dimensional (3D) cell c920.-.+ulture models turn out to be step by step progressively well known in contemporary malignant growth research and medication opposition contemplates ${ }^{(39)}$.

To information, uncommon examinations were directed to assess the impact of clove oil as normal item in mix with chemotherapeutic medications, for example, 5-FU and cisplatin in treatment of head and neck malignant growth. Subsequently, the present examination was completed to survey the impact of 5-fluorouracil versus cisplatin in mix with clove oil in the executives of head and neck squamous cell carcinoma cell line (Hep2).

Every single tried set were analyzed to assess cytotoxic impact of tried medications by MTT measure, cell cycle investigation and dimension of apoptosis by flowcytometery. MTT test [3-(4, 5-dimethylthiazol-2-yl) 2, 5 diphenyl tetrazolium bromide] of tried sets estimated viability of cells ${ }^{(23)}$. Though cell cycle investigation was utilized to ponder the impact of utilized medications on development of malignant growth cells and to evaluate the level of apoptosis in tried sets ${ }^{(40,41)}$.

In the present examination, 5-FU showed cytotoxic impact against Hep2 cell line. This could be clarified in light of the fact that the 5-FU applies its chemotherapeutic impact through restraint of thymidylate synthase compound ${ }^{(42)}$, and furthermore in view of its structure, 5-FU meddled with nucleoside digestion and fused into RNA and DNA, prompting cytotoxicity and cell demise ${ }^{(12)}$.

In the present investigation, 5-FU additionally prompted apoptosis and development capture of Hep2 malignant growth cells at G2/M stage and this as per ponder did by Liu et al. who recommended that 5-FU interceded apoptosis and G1/S cell cycle stage capture in laryngeal carcinoma through a p53autonomous pathway ${ }^{(43)}$. 
Alongside that in the present examination, 5-FU applied its cytotoxic impact on Hep-2 cell lines in portion and time dependant way contrasted with control cells and this as per the investigation completed by Galbiatti who announced that 5-FU dose may impact lethality and medication adequacy, Regarding to cells treated with 10,50 and $100 \mathrm{ng} /$ $\mathrm{mL}$ of 5-FU, the quantity of apoptotic cells expanded as the portion was expanded ${ }^{(44)}$.

The present investigation exhibited that cisplatin indicated cytotoxic impact against Hep2 cell line. And furthermore tried set treated with cisplatin displayed apoptosis and cell division capture at G2/M stage. It had been accounted for that cisplatin-instigated cell demise was associated with apoptotic-and cell cycle-managing pathways ${ }^{(45)}$. In the present examination, cisplatin applied its cytotoxic impact on Hep-2 cell lines in portion and time dependant way contrasted with control cells and this as per ponder completed by another investigator who revealed that cisplatin likewise hindered cell expansion and actuated apoptosis of Hep2 laryngeal cells in a portion and time subordinate way ${ }^{(46)}$. In this examination, A 24 hour introduction of Hep- 2 cells to $10 \mu \mathrm{M}$ cisplatin caused a decrease in G0/G1 stage cells, from $74.86 \%$ cells in the control to $43.14 \%$ cells following treatment. Additionally, flow cytometery examination of cell cycle dispersion showed that treatment of Hep-2 cells with cisplatin alone outcomes in critical cell apoptosis (sub-G1 crest). The level of apoptotic cells elevated from $1.02 \pm 0.56 \%$ for control gathering to $3.33 \pm 1.08 \%$ for cisplatin. On other hand; the IC50 of cisplatin in the present examination was $13.00 \mu \mathrm{g} / \mathrm{ml}$. The level of development capture at G2/M stage was $20.47 \pm 0.91 \%$ and the level of apoptotic cells was $22.45 \pm 1.29 \%$.

In the present examination, clove oil displayed cytotoxic impact against Hep2 cell line in portion and time dependant way contrasted with control cells and this as per other investigation revealed that eugenol in the $\mu \mathrm{M}$ run appeared at oral squamous carcinoma cells ${ }^{(47)}$. This could be clarified that eugenol in the $\mu \mathrm{M}$ go caused metabolic changes including decrease of ATP usage, oxidative pressure and an expansion in the polyamines and glycolytic metabolites ${ }^{(48)}$.

In the present investigation, tried set treated with clove oil indicated Pre-G1 apoptosis and cell division capture at G2/M stage and this as per the examination completed by researcher who revealed that eugenol in the $\mu \mathrm{M}$ extend hindered the development of melanoma cells-Sbcl2 (essential melanoma), WM1205Lu (metastatic melanoma) and this was joined by cell cycle capture at the $\mathrm{S}$ stage and pursued by apoptosis ${ }^{(49)}$. Additionally, eugenol-treated HL-60 cells (human promyelocytic leukemia), showed DNA discontinuity, ROS generation, loss of mitochondrial transmembrane potential, bax translocation, Bcl-2 decrease, cytochrome c discharge and caspase-9 and - 3activation, prescribed that eugenol caused apoptotic cell demise ${ }^{(50)}$. Moreover, dynamic portion of clove (AFC) could initiate cell apoptosis in human colorectal malignant growth HCT-116 cells by means of the phosphoinositide3kinase/Akt/mechanistic(PI3K/Akt/mTOR-intervened autophagic pathway) ${ }^{(51)}$.

A Combination treatment is the best treatment technique in disease. The basic rule for mix chemotherapy is to utilize drugs that work by various systems of activity and this prompted diminish the advancement of safe malignancy cells. This was clarified by investigator who expressed that the significance of blend treatments rising up out of free instruments of activity that could limit the advancement of medication opposition and it could give adequate disease cell slaughtering to treat a patient by conveying these medications at their most extreme endured portion, a condition that could permit improving malignant growth cell murdering with reasonable harmfulness ${ }^{(52)}$.

In the present investigation, a blend of clove oil and cisplatin demonstrated cytotoxic impact against Hep2 cell line. And furthermore tried set treated with this mix displayed apoptosis and cell division capture at G2/M stage. This could be clarified by 
study did by another researcher who revealed that a co-treatment with eugenol and cisplatin initiated various pathways and procedures related with an apoptotic reaction in human melanoma G361 cells including atomic buildup, DNA discontinuity, a decrease in MMP and proteasome action, the expansion and decline of $\mathrm{Bax}$ and $\mathrm{Bcl}-2$, a diminished DNA content, the arrival of cytochrome $\mathrm{c}$ into the cytosol and the enactment of caspase-9, caspase-7, caspase-3. Interestingly, separate medications of $300 \mu \mathrm{M}$ eugenol or $3 \mu \mathrm{M}$ cisplatin for $24 \mathrm{~h}$ did not instigate apoptosis ${ }^{(53)}$.

Additionally, the present investigation as per the examination completed by Yi and Shi who revealed that the mix of methyl eugenol with cisplatin brought about progressively strong apoptosis enlistment by expanding mitochondrial layer potential misfortune and caspase-3 action ${ }^{(54)}$. Next to that eugenol could potentiate cisplatin hostile to malignant growth action through restraint of aldehyde dehydrogenase ALDH-positive bosom disease foundational microorganisms and the NF- $x \mathrm{~B}$ flagging pathway. With the goal that our present information propose that a blend treatment of eugenol and cisplatin is a potential treatment technique for head and neck disease ${ }^{(55)}$.

In the present examination, the blend of clove oil and 5-FU indicated cytotoxic impact against Hep2 cell line. And furthermore tried set treated with this mix showed apoptosis and cell division capture at $\mathrm{G} 2 / \mathrm{M}$ stage. This as per examine completed by Hemaiswarya who announced that the blend of eugenol and 5-fluorouracil diminished human cervical HeLa cells multiplication when contrasted with the individual medicines and control. Also, there was a critical increment in the quantity of apoptotic cells in blend when contrasted with individual medications ${ }^{(56)}$.

The present examination exhibited there was huge increment in the quantity of apoptotic cells and the level of development capture in the blend when contrasted with the individual medications and control. These discoveries can prompt new treatment procedures and could likewise make ready in the decrease of the measure of anticancer specialists required as helpful portion. A decrease in the measure of the engineered medication can in the long run lead to decrease in the poisonous quality and reactions caused to the patients.

The present study demonstrated that utilized medications separately shown malignant growth development inhibitory action and when consolidated clove oil with cisplatin just as with 5-FU in explicit portion frame created synergistic improvement of the anticancer impact of cisplatin and 5-FU against the disease cells.

All in all, the blend between chemotherapeutic medications, for example, 5-FU and cisplatin and natural agent, for example, clove oil brought about synergistic impacts on development hindrance, cell cycle capture, and apoptosis acceptance. Our outcomes proposed that this kind of mix treatment may be a conceivably helpful restorative choice for people determined to have head and neck malignancy. We found that tried sets that treated with a mix of clove oil and cisplatin exhibited prevalent outcomes than sets treated with a blend of clove oil and 5-FU and them two indicated more great outcomes than other tried sets. This could be credited to autonomous systems of activity of tried medications that could limit the advancement of medication obstruction ${ }^{(52)}$.

\section{REFERENCES}

1. Divisi DDI, Salvemini S. Diet and cancer. Acta Biomed 2006; 77:118-23.

2. Ferlay J, Shin HR, Bray F, Forman D, Mathers CD, Parkin D. Cancer Incidence and Mortality Worldwide: GLOBOCAN (2008 ), IARC Cancer Base No.10. Lyon, France: International Agency for Research on Cancer Int J Cancer 2010; 127:2893-917.

3. Jemal A, Bray F, Center MM, Ferlay J, Ward E, Forman D. Global cancer statistics. CA Cancer J Clin 2011;61:69-90

4. Parkin DM, Bray F, Ferlay J, Pisani P. Global Cancer Statistics, 2002. CA Cancer J Clin 2005; 55: 74-108. 
5. Warnakulasuriya S. Global epidemiology of oral and oropharyngeal carcinoma. Oral Oncol 2009; 45: 309-16.

6. Gurova K. New hopes from old drugs: revisiting DNAbinding small molecules as anticancer agents. Future Oncol 2009; 5: 1685-704.

7. McCormick F. Cancer gene therapy: fringe or cutting edge. Nat. Rev Cancer 2001; 2:130-41.

8. Mans DRA, Jung FA, Schwartsmann G. Anticancer drug discovery and development. J. Brazilian Assoc Advancement Sci 1994; 46:7081-.

9. Longley DB, Harkin DP, Johnston PG.5-fluorouracil: mechanisms of action and clinical strategies. Nat. Rev Cancer 2003; 3:3308-.

10. Schilsky RL, Lamont EB.The oral fluorophyrimidine in cancer Chemotherapy. Clin Cancer Res 1999; 5: 2289-96.

11. Hulme AT, Price SL, Tocher DA. A new polymorph of 5-Fluorouracil found following computational crystal structure predictions. J . Am Chem Soc 2005; 127:1116-7

12. Nimg Z, Ying Y, Sheng-Jie X, Wei Shan C. 5- Fluorouracil mechanisms of resistance and reversal strategies. Moleculars 2008;13:1551-69.

13. Gregoire V, Lefebvre JL, Licitra L, Felip E, EHNS-ESMOESTRO Guidelines Working Group. Squamous cell carcinoma of the head and neck:EHNS-ESMO-ESTRO Clinical Practice Guidelines for diagnosis, treatment, and follow-up. Ann. Oncol 2010; 21: 184-6.

14. Splettstoesser F, Florea AM, Büsselberg D. IP (3) receptor antagonist, 2-APB, attenuates cisplatin induced $\mathrm{Ca} 2+-$ influx in HeLa-S3 cells and prevents activation of calpain and induction of apoptosis. Br. J. Pharmacol 2007; 151: 1176-86.

15. Hail N Jr, Lotan R. Cancer chemoprevention and mitochondria: Targeting apoptosis in transformed cells via the disruption of mitochondrial bioenergetics/redox state. Mol. Nutr. Food Res 2009; 53: 49-67.

16. Dugbartey, GJ, Peppone, LJ, Graaf, IA. An integrative view of cisplatin-induced renal and cardiac toxicities: molecular mechanisms, current treatment challenges and potential protective measures. Toxicology 2016 ;371:58-66.

17. Shan B, Cai YZ, Sun M, Corke H. Antioxidant capacity of 26 spice extracts and characterization of their phenolic constituents. JAgric Food Chem 2005; 53: 7749-59.

18. Ogata M, Hoshi M, Urano S, Endo T. Antioxidant activity of eugenol and related monomeric and dimeric compounds. Chem Pharm Bull 2000; 48: 1467-9.
19. Mihara S, Shibamoto T. Photochemical reactions of eugenol and related compounds: Synthesis of new flavor chemicals. J Agric Food Chem 1982; 30: 1215-8.

20. Aschele C, Debernardis D, Bandelloni R, Cascinu S, Catalano V, Giordani P, et al .Thymidylate synthase protein expression in colorectal cancer metastases predicts outcome to leucovorin-modulated bolus or infusional 5-fluorouracil but not methotrexate-modulated bolus 5-fluorouracil Ann Oncol 2002; 13:1882-92.

21. Cindy L, Cherly D. Basic cell culture protocols.3rd ed. Human press publication New Jersey USA;2005. p.1

22. Wei-Shou HU, and Sadettin S. Cell culture technology for Pharmaceutical and cell-based therapies.1st ed. Taylor and Francis group USA; 2006.

23. Gerlier D, Thomasset N. Use of MTT colorimetric assay to measure cell activation. J Immunol Methods 1986; 94: 57-63.

24. Chen X, Ping L, Liu J, Kangsen X. Apoptosis of human hepatocellular carcinoma cell (HepG2) induced by cardiotoxin III through S-phase arrest. Exp Toxicol Pathol 2009; 61: 307-15.

25. Zhang J,Li Y,Liu T, He W, Chen Y, Chen X, et al. Antitumor effect of matrine in human hepatoma G2 cells by inducing apoptosis and autophagy. World J Gastroenterol 2010; 16: 4281-90.

26. Vogelstein B, Kinzler KW. Cancer genes and the pathways they control. Nature medicine 2004; 10: 789-99.

27. Shield D, Ferlay J, Jemal A, Sankaranarayanan R, Chaturvedi K, Bray F, et al. The Global Incidence of Lip, Oral Cavity, and Pharyngeal Cancers by Subsite in 2012. CA Cancer J Clin 2017; 67: 51-64.

28. Stephanie FO, Aigner KR. Basics of Oncology SpringerVerlag Berlin Heidelberg 2009; 6: 17.

29. Kuno T, Tsukamoto T, Hara A, Tanaka T. Cancer chemoprevention through the induction of apoptosis by natural compounds. J. Biophys Chem 2012; 3: 156-73.

30. Pirzada NA, Ali II, Dafer RM. Fluorouracil-induced neurotoxicity Ann Pharmacother 2000; 34:35-8.

31. Saba NF, Mody MD, Tan ES, Gill HS, Rinaldo A, Takes RP, et al. Toxicities of systemic agents in squamous cell carcinoma of the head and neck (SCCHN); A new perspective in the era of immunotherapy. Crit Rev Oncol Hematol 2017; 115: 50-8.

32. Wang HM, Lin CY, Hsieh CH, et al. Induction chemotherapy with dose-modified docetaxel, cisplatin, and 5-fluorouracil in Asian patients with borderline resectable or unresectable head and neck cancer. J Formos Med Assoc 2017; 116: 185-92. 
33. Patridge E, Gareiss P, Kinch MS. An analysis of FDAapproved drugs: Natural products and their derivatives. Drug Discov Today 2015; 21: 204-7.

34. Blowman K, Magalhães M, Lemos MF, Cabral C, Pires IM. Anticancer Properties of Essential Oils and Other Natural Products. eCAM 2018; 1-12.

35. Khalil A, Rahman U,Khan MR, Sahar A, Mehmooda T, Khan M. Essential oil eugenol: sources, extraction techniques and nutraceutical perspectives. RSC Adv 2017; 7: 32669-81.

36. Legault $\mathrm{J}$ and Pichette A. Potentiating effect of betacaryophyllene on anticancer activity of alpha- humulene, isocaryophyllene and paclitaxel. J Pharm Pharmacol 2007; 59: 1643-7.

37. Kim SH, Park EJ, Lee CR, Chun JN, Cho NH, Kim IG, et al. Geraniol induces cooperative interaction of apoptosis and autophagy to elicit cell death in PC-3 prostate cancer cells. Int J Oncol 2012; 40: 1683-90.

38. Ning Ji, Lu Jiang, Peng Deng, Hao Xu, Fangman Chen, Jinli Liu, et al.Synergistic effect of honokiol and 5-fluorouracil on apoptosis of oral squamous cell carcinoma cells. J Oral Pathol Med 2017; 46: 201-7.

39. Bielecka ZF, Maliszewska-Olejniczak K, Safir IJ, Szczylik C, Czarnecka AM. Three-dimensional cell culture model utilization in cancer stem cell research. Biol Rev Camb Philos Soc 2017; 92: 1505-20.

40. Rabinovitch PS. DNA content histogram and cell cycle analysis. Meth. Cell Biol 1994; 41: 364-87.

41. Juan G, Traganos F, Darzynkiewicz Z. Methods to identify mitotic cells by flow cytometry. Meth. Cell Biol 2001; 63: 343-54.

42. Pantaleo M, Palassini E, Labiance R, Biasco G. Targeted therapy in colorectal cancer. Dig liver dis 2006; 38: 71-7.

43. Liu HC, Chen GG, Vlantis AC, Leung BC, Tong MC, van Hasselt CA. 5-fluorouracil mediates apoptosis and G1/S arrest in laryngeal squamous cell carcinoma via a p53independent pathway. Cancer J 2006; 12: 482-93.

44. Galbiatti AL, Caldas HC, Maniglia JV, Pavarino EC, Goloni-Bertollo EM. Gene expression profile of 5-fluorouracil metabolic enzymes in laryngeal cancer cell line: predictive parameters for response to 5-fluorouracilbased chemotherapy. J.biopha 2014; 68: 515-9.

45. Gaqnon V, Van Themsche C, Turner S, Leblanc V, Asselin E. Akt and XIAP regulate the sensitivity of human uterine cancer cells to cisplatin, doxorubicin and taxol. Apoptosis 2008; 13: 259-71.
46. Liu T, Peng H, Zhang M, Deng Y, Wu Z. Cucurbitacin B, a small molecule inhibitor of the Stat3 signaling pathway, enhances the chemosensitivity of laryngeal squamous cell carcinoma cells to cisplatin. Eur J Pharmacol 2010; 641:15-22.

47. Carrasco A, Espinoza C, Cardile V, Gallardo C, Cardona W, Lombardo L, et al. Eugenol and its synthetic analogues inhibit cell growth of human cancer cells (Part I). J. Braz. Chem. Soc 2008; 19: 543-8.

48. Koh T, Murakami Y, Tanaka S, Machino M, Onuma H, Kaneko M, et al. Changes of metabolic profiles in an oral squamous cell carcinoma cell line induced by eugenol. In vivo 2013; 27: 233-43.

49. Ghosh R, Nadiminty N, Fitzpatrick JE, Alworth WL, Slaga TJ, Kumar AP. Eugenol causes melanoma growth suppression through inhibition of E2F1 transcriptional activity.J Biol Chem 2005; 280: 5812-9.

50. Yoo CB, Han KT, Cho KS, Ha J, Park HJ, Nam JH, et al. Eugenol isolated from the essential oil of Eugenia caryophyllata induces a reactive oxygen species-mediated apoptosis in HL-60 human promyelocytic leukemia cells. Cancer Lett 2005; 225: 41-52.

51. Liu M, Zhao G, Zhang D, An W, Lai H, Li X, et al. Active fraction of clove induces apoptosis via PI3K/Akt/mTORmediated autophagy in human colorectal cancer HCT-116 cells. Int J Oncol 2018; 53: 1363-73.

52. Pritchard JR, Lauffenburger DA, Hemann MT. Understanding resistance to combination chemotherapy. Drug Resist Updat 2012; 15: 249-57.

53. Park JY, Jo JB, Kim IR, Kim GC, Kwak HH, Park BS. Apoptotic Effects of A Cisplatin and Eugenol Co-treatment of G361 Human Melanoma Cells. Int J Oral Biol 2011; 36: 155-62.

54. 54- Yi JL, Shi S, Shen YL, Wang L, Chen HY, Jun Zhu1, et al. Myricetin and methyl eugenol combination enhances the anticancer activity, cell cycle arrest and apoptosis induction of cisplatin against HeLa cervical cancer cell lines. Int J Clin Exp Pathol 2015; 8: 1116-27.

55. 55- Islam SS, Al-Sharif I, Sultan A, Al-Mazrou A, Remmal A, Aboussekhra A. Eugenol potentiates cisplatin anticancer activity through inhibition of ALDH-positive breast cancer stem cells and the NF- $\varkappa \mathrm{B}$ signaling pathway. Mol Carcinog 2018; 57: 333-46.

56. Hemaiswarya S, Doble M. Combination of phenylpropanoids with 5-fluorouracil as anti-cancer agents against human cervical cancer (HeLa) cell line. Phytomedicine 2013; 20: 151-8. 